\title{
PORCN Gene
}

National Cancer Institute

\section{Source}

National Cancer Institute. PORCN Gene. NCI Thesaurus. Code C132189.

This gene is involved in the lipidation of Wnt family proteins. 